Available online at: http://proceeding.rsfpress.com/index.php/pss/index

LPPM UPN “Veteran” Yogyakarta Conference Series

Proceeding on Political and Social Science (PSS)

Volume 1 Number 1 (2020): 141-147

\title{
Evaluation Of Communication Science Master Promotion Program In The Pandemic Situation Of Covid 19
}

\author{
Christina Rochayanti, Edwi Arief Sosiawan, Basuki Agus Suparno, Puji Lestari \\ Universitas Pembangunan Nasional Veteran Yogyakarta \\ Email Address christina.rochayanti@upnyk.ac.id,Email Address edwias@upnyk.ac.id, \\ Email Address basuki.agussuparno@upnyk.ac.id, Email Address \\ Puji.lestari@upnyk.ac.id
}

\begin{abstract}
A promotion strategy during a pandemic by utilizing communication technology is the right solution. The UPN Yogyakarta Master of Communication Study Program has developed a promotional strategy by improving the website which has not been maximized, both in terms of appearance, menu completeness, data recording, interactive, and the person in charge of management. The research objective is to evaluate communication technology-based promotion programs during the Covid 19 pandemic. This research method uses the Analysis and Evaluation of Website Platform and Infrastructure. The results showed that the media developed by MIKOM Masters such as Instagram, website, and email with the upnyk.ac.id domain had been used by the admin for promotional activities for new student registration, the introduction of the new color of the MIKOM logo for new branding, namely purple. In addition, the response of prospective new students is quite good and wide-reaching. Disseminate registration information outside Java and increase the number of registrants. UPNVYK MIKOM alumni also often use the tag feature on their@mikomupnyk Instagram account to just interact or create engagement with MIKOM. Utilization of technology during a pandemic also requires the development of media to other platforms such as Facebook, Twitter, and the strengthening of admin human resources who master IT and have a clear schedule in its management.
\end{abstract}

Keyword - promotion, covid 19, master of communication science, evaluation.

\section{INTRODUCTION}

This is an open access article under the CC-BY-NC license.

MIKOM's promotional activities have been relying on the alumni network of the UPN Veteran Yogyakarta Undergraduate Communication Study Program via Facebook, Twitter, Instagram, or Whatsapp. The result was that in the first two years, many alumni of the UPN Veteran Yogyakarta Undergraduate Communication Study Program chose the UPN Veteran 
Yogyakarta Communication Science Masters Study Program as an educational institution to continue their studies.

Evaluation and review of promotional activities began to be considered further. Strategic steps in promotional activities began to be synchronized between offline promotions and online promotions. Meanwhile, the demands regarding this promotion strategy must be in sync with the use of information technology. The patterns of communication behavior in accessing information and obtaining information become urgent to think about development and an increase in the interest of prospective students.

For these reasons, the development of a promotional program for the UPN Veteran Yogyakarta Master of Communication Study Program which is in line with the nuances of competition in the era of industrial revolution 4.0 is very necessary. The availability of information online is a necessity. Therefore, in the 2019 Institutional Research, a Promotion Improvement Program through IT was developed by increasing the performance of the MIKOM Website.

Last year, the promotion development of the UPN Veteran Yogyakarta Master of Communication Study Program was to develop promotion bases based on IT. The infrastructure and menus of the Web at that time were very limited. Interactive formats and automation have not been designed on the Web which is owned by the Master Study Program. Through this program, the MIKOM Website has been improved.

There are two important things that have been done in the development of the IT-based UPN Veteran Yogyakarta Communication Study Program Promotion Program, namely. The first is to increase the capacity of the Web technology infrastructure itself. Second, the development of promotional content which is packaged in a more attractive, more informative, interactive way that can be used for the purposes of managing registration forms and files, lecturer information, course information, and other institutional information. The pandemic condition demands that educational institution managers need creativity to get students and provide information related to study programs, including the S2 study program at the Department of Communication, UPN Yogyakarta. The use of information and communication technology as a promotion cannot be avoided. In the 2019 research, MIKOM already has a website, email with institutions and Instagram, as a promotional medium for getting students, it has been quite successful because it can be accessed outside Java. However, it does not mean that we are satisfied with this condition because of the tendency of students to come from universities that do not have an S@ Communication Studies program. Alumni, which were initially established as MIKOM's marketing targets, are now decreasing so that more students come from other universities. The conditions that make this research need to be continued to evaluate promotional programs during a pandemic so that in the future the better service series, more content, and features, and an admin who is good at communication technology are needed. Research on the evaluation of promotional programs has been carried out, such as Chintiya Betari Avinda I Nyoman SudiartaNi Made Oka Karini (2016). The research was conducted with the aim of evaluating the promotional strategies that have been carried out by the Department of Culture and Tourism and the 
obstacles it has experienced. Monica (2018) This study aims to analyze the implementation of PKRS at RSI Surabaya according to the standards set by the Ministry of Health of the Republic of Indonesia. Pamela Andeata, Titi Nur Vidyarini, Vita Monica (2019). This study aims to determine the evaluation of the strategy for the promotional program "Weekend Sale 2018" by Ciputra World Surabaya. Bernabas Wani (2018) This research aims to evaluate antecedent, transaction, outcomes of the boxing sports achievement development program in PPLP NTT. Research to evaluate previous promotional programs did not use internet media because it was not carried out in a pandemic. Research in 2019 for the MIKOM institution has succeeded in creating web internet networks, Instagram, and emails with the elmabga domain. For 2020, try to evaluate the development of promotional programs to communicate registration in order to get new students for the 2020 academic year and the obstacles faced

\section{LITERATURE REVIEW}

Technology has no doubt about the productivity of an organization (Miller, 2002; Pace and Faules, 2000; Pacey, 1982). Technology can help the effectiveness and efficiency of a job. Therefore, technology is used for the production and consumption processes of a particular organization. The industrial revolution 1.0 to 4.0 also reflects that technology plays a very big role and contributes to the operational characteristics of an organization and a company.

Promotional programs are programs that are key to the continued existence of an organization and a company. Promotional activities include a wide range of activities that carry out the advertising function, public relations function, informational function, and entertainment function. In a revolutionary way, the existence of the internet has changed the way individuals, groups, organizations, companies, and governments communicate and interact. The Internet overcomes the barriers of space and time more radically than any previous invention of communication technology. Through the internet, the way a person delivers messages, how to receive messages, process messages, and interpret communication messages are very different.

A seller uses the internet to sell. Companies build digital economic ecosystems, develop ecommerce, create marketplaces, applications, startups, and more. The government uses it to develop public information systems based on artificial intelligence and smart cities. Internet technology has given rise to innovations in industry and business. New business models were born. For example, Amazon is an online retailer business model, Yahoo is a portal and directory. eBay is an online auction model. Hotmail is a web-based e-mail as a form of viral marketing that Microsoft later bought in 1997. Alibaba.com is a B2B (Business to Business) marketplace. Myspace is a virtual social network. Wikipedia is an open encyclopedia. Facebook is a social network and group network (Chaffay, 2000: 4-5). In other words, information technology in particular resulting from the convergence between telecommunication technology and computers has changed the face of industry in the country with what is known as Industry 4.0. 
Revolution 4.0 brings changes to all dimensions of human life, such as in the fields of business and economy, marketing, education, government, politics, and social affairs. Economic digitization was first introduced by D Tapscott (1996) and later mentioned another term-Wikinomics by E William (2009) which broadly opened up thoughts and opportunities about economic digitization. Economic digitalization according to the World Bank is an economic, social, and cultural system based on the use of digital ICT. Digitalization of marketing, information technology has facilitated and opened the possibility of virtual marketplace models, e-commerce, online marketing, online shopping, and online sales and purchase transactions. Promotion systems, Public Relations, and Advertising strategies as keys in marketing communication strategies have also shifted to migrating to digitalization. In the industrial era 4.0, the promotional media platform has also undergone changes and adjustments along with changes in communication behavior and changes in consumer behavior. Therefore, a media platform called digital media communication emerged, which is defined as facilitated communication through messages and interactive services delivered by a number of digital technology platforms such as the internet, web, blogs, social media, mobile phones, and the like (Chaffay, 2000)

Internet marketing itself is the use of the internet and related digital media used for existing marketing functions. A number of methods are used, including using the web. This method is used to facilitate interaction between organizations and consumers in terms of exchanging data between organizations and consumers so that they can meet consumer needs and what the organization offers.

Utilization of the Webby a company or organization, because it has main characteristics which include: 1) interactive applications; 2) Has a participatory system; 3) Encourage users to produce content; 4) Usage rating can be determined; 5) Exchange of data and 6) Enrich the use of messaging platforms and media. In the era of the industrial revolution 4.0, advertising and promotion media platforms were integrated into a number of media platforms. As has been explained that the web can be integrated into a number of media platforms. Web can be integrated with social media such as Facebook, Twitter, Instagram, and Youtube.

In an advertising and promotion media plan, as mentioned by Richard (2004) the media must be positioned as a message delivery system. That is, to get the expected results, the media must be integrated into the message delivery system. All consumer behavior in using media must be used for the simultaneous effect of the competitive advantage of each media used. The web has a distinct competitive advantage over Youtube. Twitter has the advantages of Instagram and vice versa. None of the media is able to meet the complexity of consumer behavior in using media. Therefore, as a message delivery system, advertising messages and promotional messages must arrive at their intended targets. Because consumers have different behavioral characteristics in using media, and the media used are different, including media consumption patterns, various media platforms are used in advertising and promotion programs by companies and organizations 


\section{RESEARCH METHODOLOGY}

This research method uses the Analysis and Evaluation of Website Platform and Infrastructure. This analysis is to determine the number of weaknesses that include the existing infrastructure on the Website, and then take steps to improve the Website infrastructure. This procedure is a kind of internal analysis and evaluation technique of a number of functions on the Website. Conducting a Focus Group Discussion, which brings together the technical and communication aspects of thinking that are used to maximize the function of the website of the UPN Veteran Yogyakarta Master of Communication Study Program technically and communicatively. Data triangulation techniques in developing the validity of the research data carried out. This method directs researchers in collecting data, that the author is obliged to use a variety of available data sources.

\section{FINDING AND DISCUSSION}

Evaluation of the Master of Communication Science (MIKOM) Media promotion program that has been successfully held for activities in the teaching and learning process in the results of institutional research in 2019 is the website mikom.upnyk.ac.id, Instagram @mikomupnyk, and email with the UPN domain namely mikom@upnyk.ac .id. In its development, Instagram is no longer managed by students but by an admin who is specifically assigned to Mikom social media. This makes the development of Mikom more focused and more intense in producing information through existing media, especially for marketing the Mikom study program in picking up new student candidates during the Covid19 pandemic. Evaluation for media development needs to reach to other platforms such as Facebook, Twitter, and others. In developing the Mikom website, a number of features that are more flexible are needed. However, the hosting provided by UPN is difficult to upgrade and adds other features and widgets such as adding the number of visitors, real-time contact fields, and others. The difficulty of upgrading features on the web is due to the lack of human resources for managing the information media platforms used. Meanwhile, the opportunity for UPN to have a cooperative telematics and PR team. Communication with UPN's telematics and Public Relations will improve the tangled threads of media management so that the delivery of information in the context of marketing Mikom becomes wider than all lines of social media.

The potential to involve students or certain vendors in managing social media in a professional manner. This is also to increase the sense of belonging of students. The existing media content is now more intense in publishing substantive matters. On Instagram, for example, such as information on Mikom new student admissions, holiday greetings, photos of activities, and activity news. While on the website, the content is for example the elaboration of new student registration information, news of activities, news of thesis guidance. The content is also made with an attractive and simple design so as not to generate ambiguity in the delivery of information. In contrast to the previous period, which only focused on the publication of activities, while registration information still relied on information on the mikom.upnyk.ac.id web which was not very communicative. Mikom's 
social media content now also wants to highlight the color of the Mikom Study Program, namely purple. Previously, the Micom was branded with a blue color, but it was similar to the Communication Study Program so it needed an update and was in the process of updating. Based on the latest report from NapoleonCat, a Social Media Marketing analyst company based in Warsaw, Poland (Pertiwi Kompas.com.23/12/2019) until November 2019 , the number of active Instagram users in Indonesia has reached 61,610,000, so it's not wrong if MIKOM uses Instagram as a media to promote new student admissions. Content that has been successfully provided on Instagram and the website has been more intense in publishing substantive matters. On Instagram, for example, such as information on Mikom new student admissions, holiday greetings, photos of activities, and activity news. Whereas on the website, the content is for example the elaboration of new student registration information, activity news, thesis guidance news. The content is also made with an attractive and simple design so as not to generate ambiguity in the delivery of information. In contrast to the previous period, which only focused on the publication of activities, while registration information still relied on information on the mikom.upnyk.ac.id web which was not very communicative.

Mikom's social media content now also wants to highlight the color of the Mikom Study Program, namely purple. Previously, the Micom was branded with a blue color, but it was similar to the Communication Study Program so it needed an update and was in the process of updating. The initial response to the use of Whatsapp media was limited to networks owned by the Department of Communication such as Alumni, Lecturers, and Education Personnel as well as the Academic Community at UPN Veteran Yogyakarta. After using Instagram and the web, there are prospective students who come from outside the UPN Department of Communication, either from one department or from across departments. Initial human resource management at the time of running this promotion only collaborated with the Coordinator of the Micom Study Program and one educational staff and was assisted by a lecturer in the department of communication science. By utilizing the network owned by all Alumni, Lecturers, and Education Personnel as well as the Academic Community at UPN Veteran Yogyakarta, initially, they were only able to capture only a limited number of alumni and after the existence of social media Instagram and the web could increase the number of student interest in Mikom.

The result of the next evaluation is limited human resources (HR) who handle online media. This manager is not specifically for admin managers but young lecturers who have duties as teachers. This causes dalma to deliver first-rate services often late. Special staff is needed to manage the admin to make it more optimal. There is data input adding more features so that more leverage can communicate with telematics authorities authorized to implement information systems. Even so, the student's interest is quite good because new students are not dominated by alumni but from various university graduates. This shows that MIKOM UPN is well-known, however, it must be prepared to carry out better promotional media and the use of more addictive media as currently communication via online media is becoming the mainstay. Content can be more diverse and detailed. In addition, the media through 
Instagram can be used as endorsement media for alumni who have graduated so that they can provide testimonials to prospective new students.

\section{CONCLUSION AND FURTHER RESEARCH}

The results of the evaluation of promotional programs through internet media during the pandemic were quite successful. First, the response of prospective students is quite diverse, both from the region and from the university, so it is not limited to alumni, including students who do not come from the Department of Communication. The content also varies, not just registration announcements but activities carried out by MIKOM, for example, seminars, visits to a place, and greetings on holidays. The development of internet media in the future requires a special admin staff so that it can provide excellent service and a wider reach

\section{REFERENCES}

Chaffey, Dave. 2000. E-Business and E-Commerce Management. Strategy, Implementation, and Practice.Fourth Edition. Prentice-Hall

Miller, Katherine. 2002. Communication Theories: Perspective, Processes, and Contexts. New York: McGraw Hill

Moleong, Lexy J. 2007, Metodologi Penelitian Kualitatif, Penerbit PT Remaja Rosdakarya Offset, Bandung

Pace R. Wayne and Faules, Don F, 2000, Komunikasi Organisasi, Rosda Karya, Bandung

Sutopo, HB. 2002. Pengantar Penelitian Kualitatif. Surakarta : Universitas Sebelas Maret Press

Tapscott, Don. 1996. The Digital Economy Era: Promise and Peril in the Age of Networked Intelligence, New York: McGraw Hill

Kompas.com https://tekno.kompas.com/read/2019/12/23/14020057/sebanyak-inikahjumlah-pengguna-instagram-di-indonesia diakses 21 Agustus 2020. 